\title{
Optimization of the Electrodeposition Conditions for Mercury Removal from Vegetal Biomass with Response Surface Methodology
}

\author{
J.J. Marrugo-Negrete, ${ }^{a}$ J.J. Pinedo-Hernández ${ }^{a, *}$ and J.A. Baeza-Reyes ${ }^{b}$ \\ ${ }^{a}$ Water, Applied and Environmental Chemistry Group, University of Córdoba, \\ Cra $6 N^{\circ}$ 76-103 Monteria, Colombia \\ ${ }^{b}$ Department of Analytical Chemistry, Chemistry Faculty, Mexico's National Autonomous \\ University, C.P. 04510 México
}

Received 3 December 2012; accepted 14 April 2013

\begin{abstract}
It was evaluated the technical viability of mercury removal by electrodeposition from vegetal biomass samples obtained from mining zones which had $10 \pm 0.3 \mu \mathrm{gHg} \mathrm{g}^{-1}$. Each sample was treated by mixed acid to destroy the organic matter and liberate the metal in its inorganic form for the later removal of $\mathrm{Hg}$ by means of a cell of electrolysis with a rotary electrode of copper as cathode. Mercury concentration was determined by Cold Vapor Atomic Absorption Spectrophotometry (CVAAS). Response surface methodology (RSM) was applied to evaluate the simple and combined effects of three independent parameters (voltage, time and concentration) on the removal efficiency and optimizing the operating conditions. Analysis of variance showed a high coefficient of determination $\left(r^{2}=0.925\right)$ indicating that the second order regression model explains $92.5 \%$ of the variability in results. The maximum efficiency of removal $(91.2 \%)$ predicted by the model was found for the initial concentration of $1.0 \mu \mathrm{g} \mathrm{mL}^{-1}, 66.6 \mathrm{mins}$ and $34.3 \mathrm{~V}$. Model Validation was carried out under the following conditions: $1.0 \mu \mathrm{g}$ $\mathrm{mL}^{-1}, 60$ mins and $30 \mathrm{~V}$, which are close to the maximum efficiency with a removal percentage of $87.1 \%$.
\end{abstract}

Keywords: mercury, biomass, electrodeposition, Response Surface Methodology (RSM).

\section{Introduction}

Mercury is one of the metals with high impact on the ecosystems and has been the object of innumerable studies achieved by investigators from several areas [1]. Mercury (Hg), as any other chemical element, cannot be either chemistry or

\footnotetext{
*Corresponding author. E-mail address: josejph@ hotmail.com
} 
biologically degraded [2]. This metal is released into the environment by both natural and anthropogenic sources; as a global pollutant it is ubiquitous in the planet; in addition mercury bioaccumulation and biomagnification occurs across trophic chain due to its persistence, leading to negative impacts on ecosystems and public health [3]. Plants have different natural properties what are ideal to be used for cleaning up air, soils and water bodies contaminated with heavy metals. Nowadays these properties are used to implement a known green technology system which is named phytoremediation [4]. In recent years, several studies have demonstrated the mercury removal potential from soil and water through plants [5-6-7]. Nevertheless, metals are not metabolized by plants but accumulate into their biomass which causes another environmental problem [8]. Literature mentions that biomass can be confined into sanitary fillings or used like compost [9-10], fact that is not advisable at all due to the high chance of release of that pollutant into the environment, what is subjected to the changes in environmental conditions. Drying, compaction and later incineration of the vegetal biomass have been suggested for recovering metals of high commercial value [11]. Nevertheless studies about this topic are still scarce [12]. An up to date review of the existing literature proved that the only study of electrochemical removal of metals from vegetal biomass with lead removal efficiencies between 93 and $95 \%$ [13]; according to the results the application of electrochemical methods focused on removal or recovery of metals from contaminated vegetal biomass becomes necessary. The aim of this work was to evaluate the electrodeposition process of mercury removal from solutions obtained of contaminated vegetal biomass to different conditions of concentration, potential and time, optimizing the conditions of maximum removal efficiency by response surface methodology (RSM).

Table 1. Experimental design factors and levels.

\begin{tabular}{lcccc}
\hline Independent variable & Factor & \multicolumn{4}{c}{ Range and level } \\
\cline { 3 - 5 } & $\mathrm{X}_{\mathrm{i}}$ & -1 & 0 & 1 \\
\hline & & & & \\
Concentration $\left(\mu \mathrm{g} \mathrm{mL}^{-1}\right)$ & $\mathrm{X}_{1}$ & 0.5 & 1.0 & 3.0 \\
Voltage $(\mathrm{V})$ & $\mathrm{X}_{2}$ & 10 & 30 & 50 \\
Electrolysis time $(\mathrm{min})$ & $\mathrm{X}_{3}$ & 30 & 60 & 90 \\
\hline
\end{tabular}

\section{Materials and methods}

\section{Treatment of vegetal biomass}

Vegetal biomass used was Thalia geniculata. It came from the mining zone of Santa Cruz - department of Bolivar - Colombia, containing a concentration of 10 $\pm 0.3 \mu \mathrm{gHg} \mathrm{g}^{-1}$ dry weighted. Biomass was initially separated in foliage and roots, washed with distilled water, dried at $60{ }^{\circ} \mathrm{C}$ during $72 \mathrm{~h}$, crushed and ground to form a whole [14]. Biomass proportions of 12.5, 25.0 and $75.0 \mathrm{~g}$ were subjected to mixed acid digestion with $\mathrm{H}_{2} \mathrm{SO}_{4}-\mathrm{HNO}_{3}(7: 3)$ under controlled temperature water bath at $95{ }^{\circ} \mathrm{C}$ for $1 \mathrm{~h}$ or up to complete the destruction of the vegetal material in order to eliminate the organic matter and liberate the metal in 
its inorganic form [15]. Once digestion was finished, the final volume of solutions was set at a capacity of $250 \mathrm{~mL}$ with distilled water; after that the mercury concentration was measured in $\mu \mathrm{g} \mathrm{mL} \mathrm{m}^{-1}$ units (Table1). This solution was used later in the electrodeposition process. $\mathrm{Hg}$ concentrations were determined by Cold Vapor Atomic Absorption Spectrophotometry methods, adapted for analysis of plant samples and water [15-16]. Samples were analyzed in triplicate and concentrations were reported as $\mu \mathrm{g} \mathrm{Hg} \mathrm{mL}{ }^{-1}$ (liquid matrix) and $\mu \mathrm{Hg} \mathrm{g}^{-1}$ (solid matrix).

Table 2. Factorial design $3^{3}, \mathrm{n}=3$.

\begin{tabular}{|c|c|c|c|c|c|}
\hline \multirow{2}{*}{ Essay } & \multirow{2}{*}{ Voltage (V) } & \multirow{2}{*}{$\begin{array}{c}\text { Concentration } \\
\left(\mu \mathrm{g} \mathrm{mL} L^{-1}\right)\end{array}$} & \multirow{2}{*}{ Time (min) } & \multicolumn{2}{|c|}{ Percentage of Remova } \\
\hline & & & & $\operatorname{Exp}$ & Pred \\
\hline 1 & -1 & -1 & -1 & 50.1 & 52.0 \\
\hline 2 & -1 & -1 & 0 & 80.5 & 89.8 \\
\hline 3 & -1 & -1 & 1 & 83.8 & 94.0 \\
\hline 4 & -1 & 0 & -1 & 38.2 & 39.9 \\
\hline 5 & -1 & 0 & 0 & 69.9 & 78.2 \\
\hline 6 & -1 & 0 & 1 & 86.9 & 82.9 \\
\hline 7 & -1 & 1 & -1 & 23.5 & 21.5 \\
\hline 8 & -1 & 1 & 0 & 57.7 & 61.7 \\
\hline 9 & -1 & 1 & 1 & 61.2 & 68.2 \\
\hline 10 & 0 & -1 & -1 & 54.1 & 66.0 \\
\hline 11 & 0 & -1 & 0 & 88.1 & 102.6 \\
\hline 12 & 0 & -1 & 1 & 89.9 & 105.5 \\
\hline 13 & 0 & 0 & -1 & 59.7 & 53.7 \\
\hline 14 & 0 & 0 & 0 & 87.1 & 91.2 \\
\hline 15 & 0 & 0 & 1 & 91.0 & 94.1 \\
\hline 16 & 0 & 1 & -1 & 37.3 & 34.2 \\
\hline 17 & 0 & 1 & 0 & 70.7 & 73.1 \\
\hline 18 & 1 & 1 & 1 & 82.9 & 78.3 \\
\hline 19 & 1 & -1 & -1 & 65.3 & 73.0 \\
\hline 20 & 1 & -1 & 0 & 85.2 & 108.3 \\
\hline 21 & 1 & -1 & 1 & 87.5 & 109.9 \\
\hline 22 & 1 & 0 & -1 & 70.2 & 60.4 \\
\hline 23 & 1 & 0 & 0 & 84.0 & 96.1 \\
\hline 24 & 1 & 0 & 1 & 87.1 & 98.2 \\
\hline 25 & 1 & 1 & -1 & 36.2 & 39.9 \\
\hline 26 & 1 & 1 & 0 & 73.7 & 77.5 \\
\hline 27 & 1 & 1 & 1 & 84.5 & 81.4 \\
\hline
\end{tabular}

\section{Experimental design}

Three factors were considered for developing the experiments: Hg concentration, applied potential and electrodeposition time. Percentage of mercury removal from solutions prepared with digested vegetal biomass was established as the response variable. The experimental design consisted of three factors at three levels each one (Table 1), which involved a completely random design with 
factorial structure $3^{3}$ illustrated in Table 2 [17]. Levels of every factor were evaluated in triplicate, 81 essays in the whole process. With the purpose of evaluating matrix interferences for any other metal, independent electrodeposition essays were realized with synthetic solution of mercury $3.0 \mu \mathrm{g}$ $\mathrm{mL}^{-1}$ to potentials of 10,30 and 50 Volts, simulating the electrolytic media by means of mixed acid addition $\mathrm{H}_{2} \mathrm{SO}_{4}-\mathrm{HNO}_{3}$ (7:3) as made in the digestion process.

The percentage of mercury removal was evaluated by determining the decreasing of the initial mercury concentration into the biomass solution digested as a function of the electrodeposition time. The equation to calculate the removal efficiency in the experiments was:

$$
\text { Removal } \%=\frac{C_{i}-C_{f}}{C_{i}} \times 100
$$

where $C_{f}$ : final $\mathrm{Hg}$ concentration ; $C_{i}$ : initial $\mathrm{Hg}$ concentration.

\section{Electrodeposition cell}

The experimental scheme is indicated in Fig. 1. The volume used for every essay was $250 \mathrm{~mL}$ of digested biomass, which were added into an electrodeposition cell made up by a cylindrical plastic container with the following dimensions: 5.0 $\mathrm{cm}$ (height) per $8.4 \mathrm{~cm}$ (diameter), provided with a cylindrical rotary copper electrode (cathode) to 1600 RPM to provide agitation to the system, against to a steel electrode (anode) connected to a DC power supply - PHYWE 0-50V. Dimensions of the electrodes were: $15 \mathrm{~cm}$ (length) per $2.0 \mathrm{~cm}$ (diameter). Distance between electrodes was $6.0 \mathrm{~cm}$. Entire submerged surface of every electrode was $31.4 \mathrm{~cm}^{2}$.

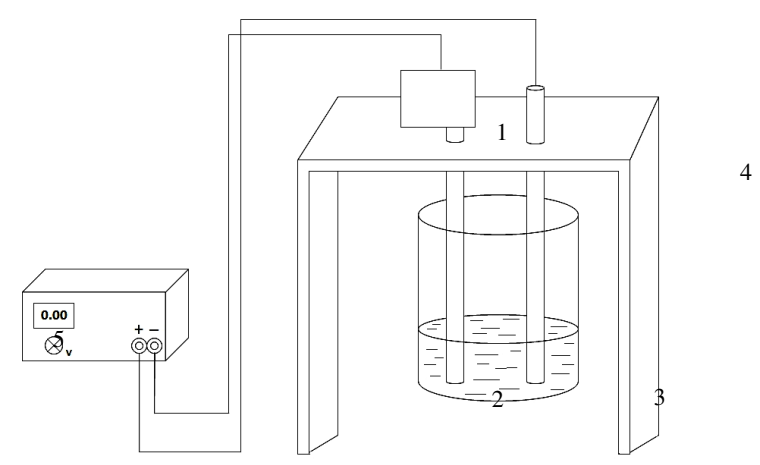

Figure 1. Electrodeposition cell. 1-Agitators, 2-Copper electrode, 3-Steel electrode, 4Support, 5-Power.

\section{Results and discussion}

\section{Selection of the electrode material}

In this study copper was used as cathode for carrying out the electrodeposition process and recovering the solved mercury into the solution of digested biomass, since this element can form an amalgam with mercury by reduction of $\mathrm{Hg}^{+2}$ to $\mathrm{Hg}^{0}$ [18], due to the ion migration from the solution and its linkage to the electrode surface by electro reduction when sufficient potential difference is 
applied. The anode electrode material was the naturally inert or steady steel, which transfers and receives electrons in the solution to generate the electrolysis process [19]. When a cylindrical rotary electrode is used as a cathodic cell, it is named cell of rotary electrodes [20], in which the electrode rotation causes a permanent homogeneity, a controlled convective regime into the solution, more uniform electrode coverings and suitable ionic transport; all of that favors the changes from the cathode zone with the rest of the electrolyte, improving this way the metal deposition [21].
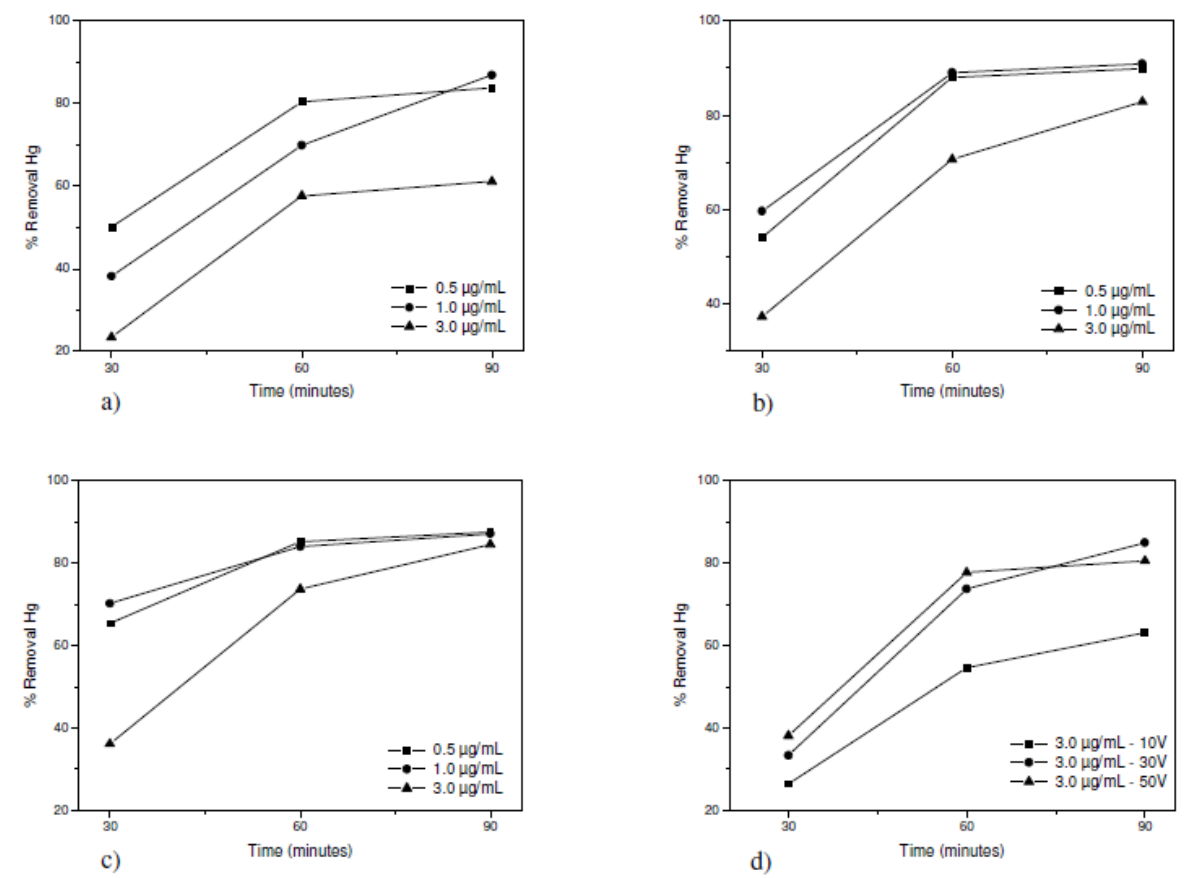

Figure 2. Removal percentage of mercury from samples. a) $10 \mathrm{~V}$, b) $30 \mathrm{~V}$, c) $50 \mathrm{~V}$. d) Removal percentage of mercury from synthetic samples $3.0 \mu \mathrm{g} \mathrm{mL}^{-1}$. $0.5 \mu \mathrm{g} \mathrm{mL}^{-1}$, $\bullet 1.0 \mu \mathrm{g} \mathrm{mL}^{-1}, \mathbf{\Delta} 3.0 \mu \mathrm{g} \mathrm{mL}^{-1}$.

\section{Hg removal function of time, potential and concentration}

The mercury removal as a function of the time and applied potential for the different evaluated concentrations appears in the Fig. 2. When keeping a constant concentration when the potential increases, the removal efficiency gets higher in a lower electrodeposition time for every essay. Considering the potential variation at a constant concentration, it is observed that the response variable increases according to the time. When the electrodeposition process is evaluated in a synthetic sample of mercury of $3.0 \mu \mathrm{g} / \mathrm{mL}$ to different potentials, (Fig. 1d), the variable response behavior was similar to the one presented with samples, which indicates that there are no matrix interferences by another metal presence into the biomass sample able to affect the process. The efficiency of mercury removal in all the essays was high for an electrodeposition time of $90 \mathrm{~min}$, despite that the initial $\mathrm{Hg}$ concentration and the applied potential between all essays were different. This result indicates that the electrodeposition process is efficient independently of the initial mercury concentration and applied potential for the concentration levels evaluated. The high percentage of mercury removal obtained is possibly owed to the high absorption rate of this element on the 
cathode surface, since it is able to form an amalgam with copper $(\mathrm{Hg}-\mathrm{Cu})$ when the reduction of $\mathrm{Hg}^{+2}$ to $\mathrm{Hg}^{0}$ in solution is presented [18].

\section{Optimization of the treatment conditions}

The effect of three electrochemical variables on mercury recovery: voltage, time and initial concentration were analyzed according to the completely randomized design with factorial structure $3^{3}$ (Table 2). The experimental design was used to determine simple and combined effects of operating variables on the efficiency of the mercury removal. The experimental data were fitted into a second order regression model. The second order regression model used to correlate dependent and independent variables was the following one:

$y=b_{0}+b_{1} x_{1}+b_{2} x_{2}+b_{3} x_{3}+b_{11} x_{1}^{2}+b_{22} x_{2}^{2}+b_{33} x_{3}^{2}+b_{12} x_{1} x_{2}+b_{13} x_{1} x_{3}+b_{23} x_{2} x_{3}$ (2)

where $y$ is the response variable of the removal efficiency, $b_{0}$ is a constant, $b_{1}, b_{2}$ and $b_{3}$ are the regression coefficients of linear effects, $b_{11}, b_{22}$ and $b_{33}$ are the second grade coefficients, and $b_{12}, b_{13}$ and $b_{23}$ are the interaction coefficients.

Table 3. Estimated regression coefficients and corresponding $t$ Student and significance level.

\begin{tabular}{ccccc}
\hline Coeficient & Value & Standard deviation & $\boldsymbol{t}$ & Significance level \\
\hline$b_{0}$ & -14.439 & 3.681 & -3.92 & 0.0001 \\
$b_{1}$ & -33.845 & 4.197 & -5.96 & $<0.0001$ \\
$b_{2}$ & 1.133 & 0.161 & 7.03 & $<0.0001$ \\
$b_{3}$ & 2.952 & 0.074 & 40.02 & $<0.0001$ \\
$b_{11}$ & 5.994 & 1.156 & 5.18 & $<0.0001$ \\
$b_{22}$ & -0.009 & 0.002 & -3.55 & 0.0004 \\
$b_{33}$ & -0.019 & 0.001 & -25.87 & $<0.0001$ \\
$b_{12}$ & -0.027 & 0.027 & -0.99 & 0.320 \\
$b_{13}$ & -0.031 & 0.017 & -1.80 & 0.073 \\
$b_{23}$ & -0.002 & 0.001 & -1.99 & 0.048 \\
\hline
\end{tabular}

Table 2 indicates the following values: regression coefficient, standard deviation, $\mathrm{t}$ and significance level. These values allowed identifying the significant variables, to isolate the effects of the interference variables and to generate a second order regression model with the experimental results as a function of voltage, concentration and electrodeposition time. Linear factors $\left(b_{1}, b_{2}, b_{3}\right)$, quadratic factors $\left(b_{11}, b_{22}, b_{33}\right)$ and the interaction $\left(b_{23}\right)$ are significant at a level less than $5 \%$. Interactions between factors $b_{12}$ and $b_{13}$ were no significant for a significance level of $5 \%$. Therefore, concentration (coefficient $b_{1}$ ), voltage (coefficient $b_{2}$ ), electrolysis time (coefficient $b_{3}$ ), interaction between voltage and time (coefficient $b_{23}$ ) and the quadratic effect of all variables (coefficients $b_{11}$, $\left.b_{22}, b_{33}\right)$ are the most influential factors. The application of RSM on the base of parameters estimation (Table 3) generates the second order regression model, where the removal percentage $(y)$ and the independent variables studied are related. 


$$
\begin{aligned}
& \mathrm{y}=-14.439-33.845 \mathrm{x}_{1}+1.133 \mathrm{x}_{2}+2.952 \mathrm{x}_{3}+5.994 \mathrm{x}_{1}{ }^{2}-0.009 \mathrm{x}_{2}^{2}-0.019 \mathrm{x}_{3}{ }^{2}- \\
& \begin{array}{l}
0.027 \mathrm{x}_{1} \mathrm{x}_{2} \\
\quad-0.031 \mathrm{x}_{1} \mathrm{x}_{3}-0.002 \mathrm{x}_{2} \mathrm{x}_{3}
\end{array}
\end{aligned}
$$

The analysis of variance (Table 4) indicates that the predictive model assures in a representative way around $99 \%$ of the experimental data, since the significance level calculated from the relation between mean square and regression was $<0.01$. As recommended in the literature, the coefficient of determination $\left(r^{2}\right)$ should be at least $75 \%$ [17] to consider the possibility of using RSM. In this study case a high coefficient of determination $\left(r^{2}=0.925\right)$ was obtained, which implies that $93 \%$ of the variations in $\mathrm{Hg}$ removal efficiency are explained through independent variables, and $7 \%$ of variations cannot be explained by the

\begin{tabular}{|c|c|c|c|c|c|}
\hline Source & $\begin{array}{l}\text { Sum of } \\
\text { squares }\end{array}$ & $\begin{array}{l}\text { Degree of } \\
\text { freedom }\end{array}$ & $\begin{array}{c}\text { Mean } \\
\text { square }\end{array}$ & F-Value & $\begin{array}{c}\text { Significance } \\
\text { level }\end{array}$ \\
\hline Regression & 534105 & 9 & 59345 & 12.4 & $<0.01$ \\
\hline Residual & 43124 & 9 & 4792 & & \\
\hline Total & 577229 & 18 & & & \\
\hline
\end{tabular}
model.

Table 4. Analysis of the variance for removal efficiency.

It is observed that the results of the second order regression model present significant correlations with the results obtained experimentally $(r=0.95, p=0.01$, $n=27$; Fig. 3). The model generates the optimum values for the maximum $\mathrm{Hg}$ removal efficiency as a function of concentration, voltage and time (Table 5). Significant differences were not observed $(p<0.05)$ when a point near to the maximum response is compared to the corresponding experimental value what confirms that RSM can be used to optimize the process parameters.

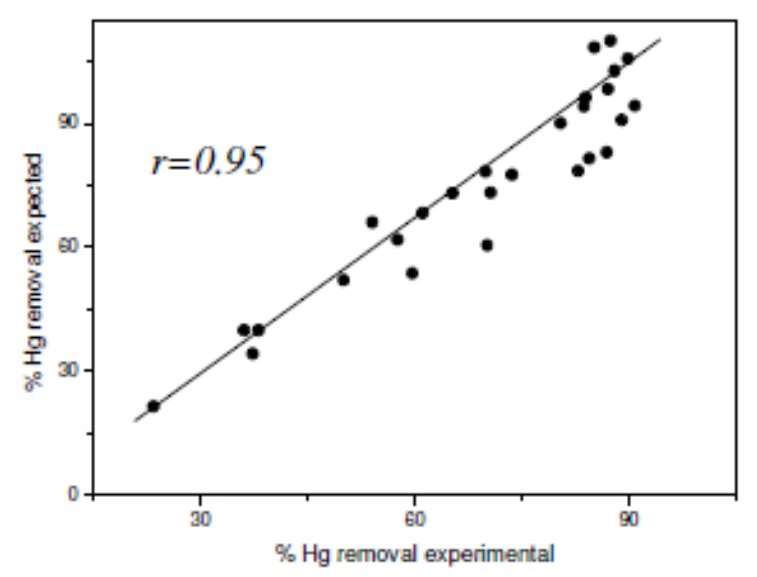

Figure 3. Experimental percentage of mercury removal and percentage of mercury removal predicted by the second order model regression. 
Table 5. Optimum values of the process parameters for the maximum $\mathrm{Hg}$ removal efficiency.

\begin{tabular}{lcc}
\hline Parameter & $\begin{array}{c}\text { Optimum } \\
\text { value }\end{array}$ & $\begin{array}{c}\text { Experimental } \\
\text { value }\end{array}$ \\
\hline Hg removal efficiency $(\%)$ & 91.2 & 87.1 \\
Concentration $\left(\mu \mathrm{g} \mathrm{mL}^{-1}\right)$ & 1.0 & 1.0 \\
Voltage $(\mathrm{V})$ & 34.6 & 30 \\
Time $(\mathrm{min})$ & 66.6 & 60 \\
& & \\
\hline
\end{tabular}

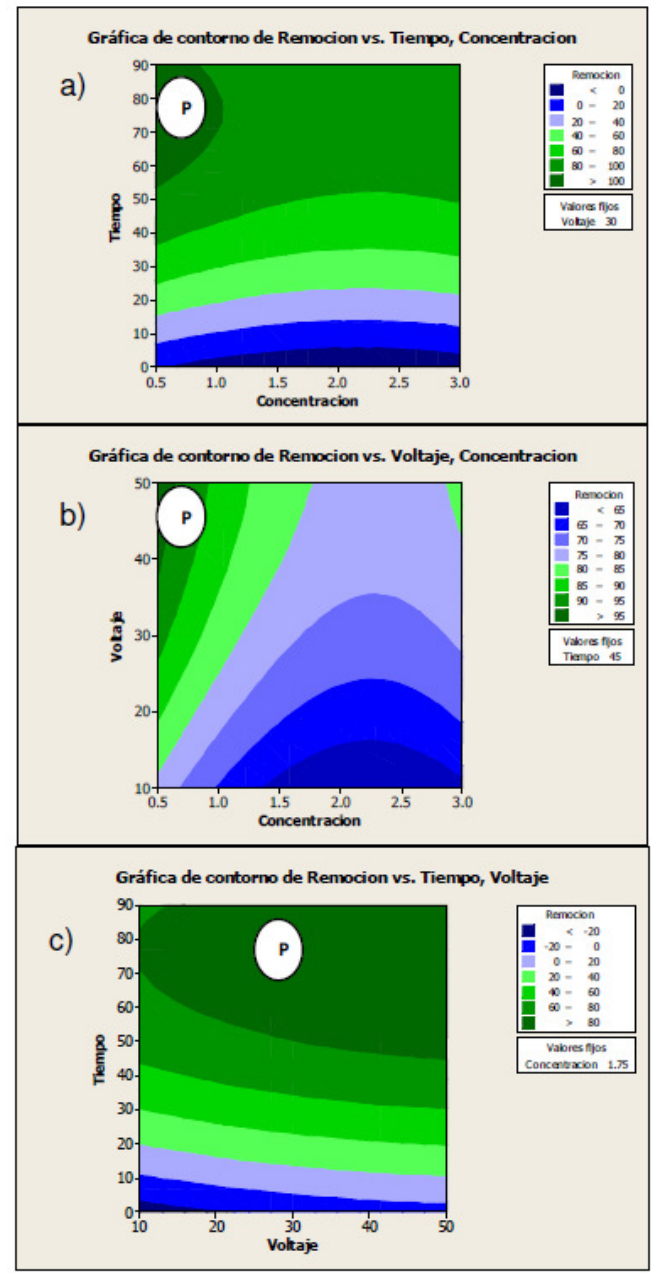

Figure 4. Contour plot. a) Time-concentration, b) voltage-concentration, c) timevoltage.

Later, to prove the significance of the model effects, the results were analyzed with the help of both plots: contour and their respective surface response for evaluating the interaction between variables. Fig. 4a-c shows the twodimensional contour plots to facilitate the interpretation of interactions between variables. Every color stripe contains an infinite number of the next kind of combinations: concentration-time, concentration-voltage, voltage-time, for which ones the average recovery predicted is in a certain range; for example, it is possible to observe that the stripe indicated with the letter $\mathrm{P}$ for every contour plot contains the combinations of the variables of interest, which can estimate the average recoveries between $80 \%-100 \%, 90 \%-95 \%$ and higher than $80 \%$. Either way the average response for a single point can be estimated by tracing the 
cut point between the interest coordinates or applying the regression equation, keeping constant a variable and manipulating other variables of interest. The response surface calculated on the basis of the model (Fig. 5) allows visualizing the behavior of the response variable and indicates clearly the combination of levels of the factors that lead to a maximum value. In this study it is observed that the best results are in the red region, where the interaction of the factors leads to results between 80 and $100 \%$.

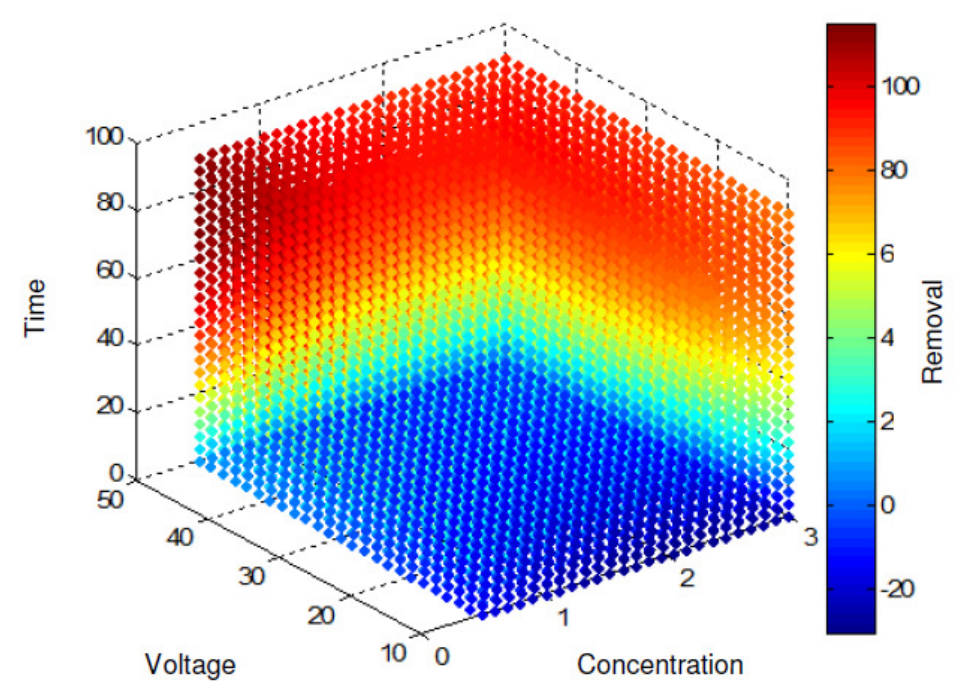

Figure 5. Three-dimensional response surface removal of $\mathrm{Hg}$ expected in terms of concentration $\left(\mu \mathrm{g} \mathrm{mL}^{-1}\right)$, time (minutes) and voltage $(\mathrm{V})$.

\section{Conclusion}

Mercury electrodeposition by means of copper electrode as cathode is a technically viable alternative for the treatment of contaminated biomass. This study demonstrated that the response surface methodology is an adequate method to optimize the operation conditions and to maximize the mercury removal from digested vegetable biomass. The analysis of variance showed a high coefficient of determination $\left(r^{2}=0.925\right)$ which guarantees a satisfactory adjustment of the second order regression model to the experimental information. The response surface and contour plots can be used for locating an optimum point. The applied electrochemical treatment allowed the removal of $\mathrm{Hg}$ in $87.1 \%$ under conditions of optimal electrodeposition: $30 \mathrm{~V}, 60$ minutes and concentration of $1.0 \mu \mathrm{g} \mathrm{mL}^{-1}$.

\section{Acknowledgements}

The authors are grateful to the Colombian Institute for the development of science and technology "Francisco José de Caldas" - COLCIENCIAS the financing of the project code 1112-489-25604 contract 472 Colciencias - Universidad de Córdoba. 


\section{Optimización de las condiciones de electrodeposición para la remoción de mercurio a partir de biomasa vegetal con metodología de superficie de respuesta}

\section{Resumen}

Se evaluó la viabilidad técnica de remoción de mercurio mediante electrodepósito aplicado a una muestra de biomasa vegetal, obtenida de zonas de explotación minera que contenía $10 \pm 0.3 \mu \mathrm{gHg} \mathrm{g}{ }^{-1}$. La muestra fue tratada con una mezcla de ácidos para destruir la materia orgánica y liberar el metal en su forma inorgánica, para la posterior remoción de $\mathrm{Hg}$, mediante una celda de electrolisis con electrodo rotatorio de cobre como cátodo. La concentración de mercurio fue determinada por espectrofotometría de absorción atómica por vapor frío (CVAAS). La metodología de superficie de respuesta (MSR) se aplicó para evaluar los efectos simples y combinados de los tres parámetros independientes, voltaje, tiempo y concentración sobre la eficiencia de remoción y la optimización de las condiciones de operación. El análisis de varianza mostró un alto coeficiente de determinación $\left(r^{2}=0.925\right)$ indicando que el modelo de regresión de segundo orden explica el $92.5 \%$ de la variabilidad de los resultados. La máxima eficiencia de remoción $(91.2 \%)$ predicha por el modelo se obtuvo para una concentración inicial de $1.0 \mu \mathrm{gHg} \mathrm{mL}^{-1}, 66.6 \mathrm{~min}$ y $34.3 \mathrm{~V}$. La validación del modelo se realizo a $1.0 \mu \mathrm{gHg} \mathrm{mL} \mathrm{m}^{-1}, 60 \mathrm{~min}$ y $30 \mathrm{~V}$, condiciones alrededor de las de máxima eficiencia con porcentaje de remoción de $87.1 \%$.

\section{References}

1. Horvat M. Anal Bioanal Chem. 2002;374:981.

2. Sánchez JE, Sanz-Medel A. Talanta. 1998;47:509.

3. Boening WD. Chemosphere. 2000;40:1335.

4. Bennicelli R, Stepniewska Z, Banach A, et al. Chemosphere. 2004;55:141.

5. He YK, Sun JG, Feng XZ, et al. Cell Research. 2001;11:231.

6. Bizily SP, Rugh CL, Meagher RB. Nature Biotechnology. 2000;18:213.

7. Rugh CL, Wilde HD, Stack NM, et al. Proc Nat Acad Sci USA. 1996;93:3182.

8. Ehsan M, Molumeli PA, Espinosa VE, et al. J Appl Sci. 2007;7:2380.

9. Ghosh MS, Singh P. Asian J Energy Environ. 2005;6:214.

10. Dushenkov V, Kumar AN, Motto H, eI. Raskin. Environ Sci Tech. 1995;29:1239.

11. Brooks RR, Chambers MF, Nicks LJ, Robinson BH. Trends in Plant Science. 1998;3:359.

12. Sas-Nowosieslska A, Kucharski R, Malkowski E, et al. Environ. Pollut. 2004;128:373.

13. Núñez-López RA, Meas-Vong Y, Gama SC, et al. J Hazard Mater. 2008; $154: 623$.

14. Romero Núñez SE, Marrugo Negrete JL, Arias Rios JE, et al. Water Air Soil Pollut. 2010;216:361.

15. Sadiq M, Zaidi T, Al-Mohana M. Bull Environ Contam Toxicology. 1991;47:335. 
16. USEPA. Methods 245.1, 245.5 and 245.6 for determination of mercury in water and tissues. Cincinnati, Ohio: U.S. Environmental protection agency; 1994.

17. Montgomery DC. Design and analysis of experiments. Nebraska: John Wiley \& Sons; 2000.

18. P. Huttencloh, K. Roehl, K. Czurda. Environ. Sci. Technol. 2003;37:4269.

19. S.S. Djokic. Electrodeposition: Theory and Practice (Modern Aspects of Electrochemistry). Springer. (2010) 284-294.

20. Walsh F, Reade G. Analyst. 1994:119.

21. Julve E. Electrodeposición de metales. Fundamentos, operaciones e instalaciones. Grupo EMA-E.S.L. España; 2000. P.29-70. 